\title{
What's in a name? Some early and current issues in dendritic cell nomenclature
}

\author{
David Vremec ${ }^{1}$ and Ken Shortman ${ }^{1,2,3 *}$ \\ ${ }^{1}$ The Walter and Eliza Hall Institute, Melbourne, VIC, Australia, ${ }^{2}$ Department of Medical Biology, The University of Melbourne, \\ Melbourne, VIC, Australia, ${ }^{3}$ Burnet Institute, Melbourne, VIC, Australia
}

Keywords: dendritic cells, DC subsets, monocytes, macrophages, nomenclature

The name dendritic cell (DC) was given by Steinman to describe the unusual cell type he saw in spleen cell suspensions. This morphological description is not sufficient to specify the cell of so much interest to immunologists; many cells can adopt a similar form. A useful functional definition evolved as Steinman and colleagues explored the immunological properties of this novel cell type (1). DCs were considered as antigen collecting and processing cells able to present antigen on MHC molecules and efficiently activate even primary T-cells. Nowadays, immunologists would likely add to this definition, a capacity to sense the context in which the antigen was collected, via receptors for pathogen or damaged cell-derived material. Why might we need to go beyond the name "dendritic cell" for cells with these well-understood functions? Some limitations of this single name arose early in DC research. This article surveys some problems of definition encountered in past work from our own laboratory. The problems we encountered arose from two sources, the first the discovery

OPEN ACCESS

Edited by: Martin Guilliams,

Ghent University - VIB, Belgium

Reviewed by: Elodie Segura, Institut Curie, France

Steffen Jung,

Weizmann Institute of Science, Israel

*Correspondence:

Ken Shortman

shortman@wehi.edu.au

Specialty section: This article was submitted to Antigen Presenting Cell Biology, a section of the journal Frontiers in Immunology

Received: 10 April 2015 Accepted: 14 May 2015 Published: 29 May 2015

Citation:

Vremec D and Shortman K (2015)

What's in a name? Some early and current issues in dendritic cell nomenclature.

Front. Immunol. 6:267.

doi: 10.3389/fimmu.2015.00267 of different DC subsets and the need to determine whether these represented different maturation states or separate sub-lineages. The second was the difficulty in distinguishing these DC subsets from macrophages.

Our first hint that there could be distinct types of DCs came from our studies with Wu and Ardavin on thymic T and DC development (2). We were surprised to find that a high proportion of mouse thymic DCs stained with antibodies against characteristic T-cell markers, such as CD8 $\alpha$; it was a relief to find they did not stain with antibodies against CD3 or the T-cell receptor! Pickup of material from thymocytes was eliminated as an explanation. We then found a similar but less frequent DC subset staining for surface CD8 $\alpha$ among the DCs in mouse spleen and these DCs were shown to express mRNA for CD8 $\alpha$ (3). Others had already reported some staining of DCs with anti-CD8; our work emphasized that these $\mathrm{CD} 8{ }^{+}$DCs were a distinct population, CD8 $\alpha$ expression being positively correlated with expression of DEC205 but inversely correlated with expression of other markers such as CD4, CD11b, and, as illustrated in Figure 1, $\operatorname{SIRP} \alpha(4,5)$.

Immunological interest in the $\mathrm{CD}^{+}$and $\mathrm{CD} 8^{-}$DC subsets increased when it became apparent from the work of many laboratories that these DCs differed in immunological functions. Differences were apparent in the expression of toll-like and other microbial pattern recognition receptors, in the cytokines produced on activation, in the fate of the T-cells they stimulated, in their capacity to phagocytize dead cells, and in the processing of antigens for MHC class I versus MHC class II presentation [reviewed in Ref. (7)]. The key findings from our laboratory were that the CD8 ${ }^{+} \mathrm{DCs}$, when appropriately stimulated, were the most potent producers of IL12p70 (8), and that the CD8 ${ }^{+}$ DCs have a strong bias to cross-presenting exogenous antigens, both soluble and particulate, for MHC class I presentation $(9,10)$.

An important issue became whether these functionally distinct DC types represented different lineages, or were simply different maturation states within one very plastic lineage. There was direct evidence, confirmed by us, that some $\mathrm{CD} 8^{-}$DCs could on adoptive transfer, produce CD8 ${ }^{+}$DCs. However, these $\mathrm{CD} 8^{+}$DCs proved to be generated from a small number of early members of the 


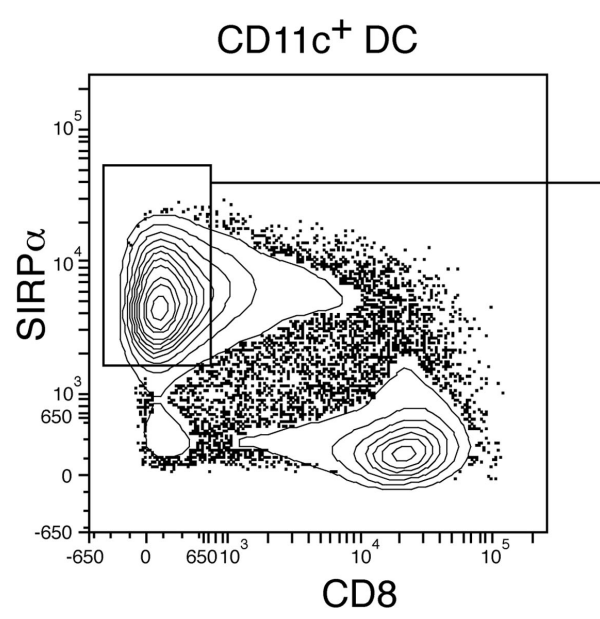

FIGURE 1 | Segregation of conventional DC subsets in mouse spleen.

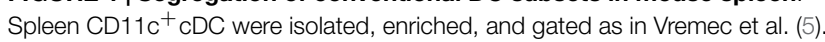
Staining for CD8 $\alpha$ and SIRP $\alpha$ allows clear segregation into the DC1 (CD8 ${ }^{+}$DC)

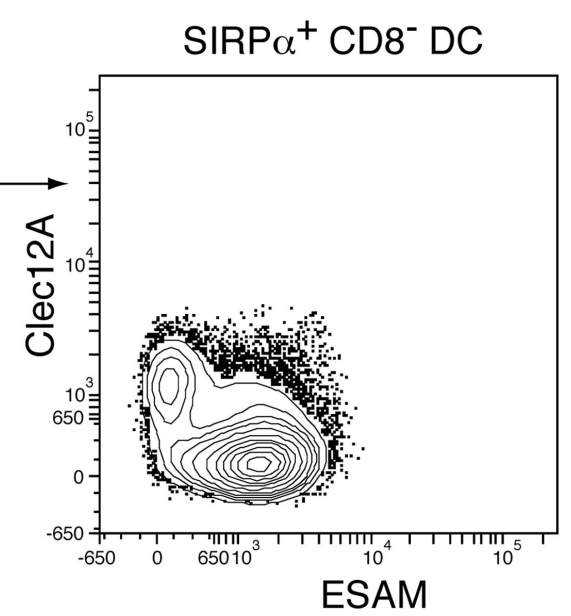

and DC2 (CD8 ${ }^{-}$DC) subsets. However, the DC2 population can be separated into two further subsets by several surface markers, here Clec12A and ESAM as demonstrated in Lewis et al. (6).
$\mathrm{CD}^{+}$DC lineage that had not yet acquired CD8 $\alpha$ expression; the bulk of $\mathrm{CD}^{-}$DCs did not give rise to $\mathrm{CD}^{+}$DCs (11). Although sequential maturation states were found within the $\mathrm{CD}^{+}{ }^{+} \mathrm{DC}$ lineage, with early forms lacking CD8 $\alpha$ expression (12) and the earliest stages lacking capacity for antigen cross-presentation (13), there was a clear developmental separation from the bulk of CD8 ${ }^{-}$ DCs. A further distinct DC type in mouse spleen became evident when the mouse equivalent of the human type 1 interferonproducing plasmacytoid dendritic cell (pDC) was identified (14). Although some pDCs expressed $\operatorname{CD} 8 \alpha$ (15), they were clearly a separate lineage from the $\mathrm{CD}^{+}$conventional DCs (cDCs). Our subsequent work with Naik showed that spleen $\mathrm{CD} 8^{+} \mathrm{DCs}$ and $\mathrm{CD} 8^{-}$DCs represented separate $\mathrm{CDC}$ sub-lineages derived via pre-DC populations from a bone marrow pro-DC or common dendritic cell precursor (CDP) (16-18). Thus, because of differences in surface phenotype, immunological functions, and developmental pathways, these two spleen $\mathrm{CDC}$ populations had to be distinguished, and the terms $\mathrm{CD}^{+} \mathrm{cDC}^{\mathrm{c}}$ and $\mathrm{CD} 8{ }^{-} \mathrm{cDC}$ became current.

In line with the pioneering work of Salomon et al. (19) and Anjuere et al. (20), we extended our analysis of DC subtypes from mouse spleen to mouse lymph nodes (LNs) $(4,21)$. Spleen should contain only what we termed the "lymphoid tissue resident" cDCs whereas LNs should contain both these and the "migratory" cDC type arriving via the lymph from other tissues. It was immediately apparent that the level of DC heterogeneity was greater than in spleen. One source of heterogeneity was the existence of different activation states within even one DC lineage. In particular, the DC that had migrated even in steady state from peripheral tissues such as skin into LNs were more activated than those remaining in skin, and more activated than their lymphoid tissue resident counterparts; the DCs that had migrated expressed higher surface levels of MHC class II and of co-stimulator molecules such as CD86. Although they were first called "mature" DCs they proved to be not fully activated but "semi-mature"; they were not producing cytokines and were likely tolerogenic (22). A similar transformation termed "spontaneous activation" occurred when spleen cDCs were isolated and placed in culture (23). In both cases, further signals, such as given by microbial products interacting with TLR ligands, were required to produce a fully active, cytokine secreting immunogenic DC. However, even when these different activation states were considered, further $\mathrm{CDC}$ subsets not found in spleen were apparent, such as the epidermal Langerhans cell-derived LN DCs. The full lineage complexity of $\mathrm{LN}$ has now been well delineated by other laboratories, a notable finding being the existence of a migratory form of the $\mathrm{CD}^{+}{ }^{+} \mathrm{DC}$ lineage but lacking $\mathrm{CD} 8 \alpha$ expression, commonly termed as the $\mathrm{CD}_{103}{ }^{+}$cDCs (24-26).

Our second problem with DC nomenclature arose as we attempted to distinguish DCs from macrophages, a particularly difficult exercise in inflamed tissues. It was also difficult to relate the DC populations we isolated from steady state mouse spleen with the DCs produced by culture of monocytes with granulocyte-macrophage colony stimulating factor (GM-CSF), a well-established model of DC generation (27). At that time, it was generally assumed that all DCs and macrophages would be bone marrow derived cells, with monocytes as the common late precursor. Some questioned whether it was valid even to consider DCs as a separate entity rather than as a macrophage variant (28). We had some sympathy with this view, since in experiments with Metcalf we had difficulty in segregating DCs from macrophages in the peritoneal fluid from mice expressing high levels of GMCSF (29). Although cells with DC function and surface phenotype could be segregated from macrophages at the extremes of the distribution, there appeared to be a continuum of phenotypes rather than two discrete populations. For us the clarification came when, with Naik, the immediate precursor of the spleen $\mathrm{cDC}$ was isolated and shown to be distinct from monocytes and unable to produce macrophages (16). We termed these pre-DCs. This led to the view that there were two different routes to cells with DC antigen presenting function, one via monocytes and more often found under conditions of inflammation, the other derived 
from $\mathrm{CDP} /$ pro-DC precursors in bone marrow then via pre-DC to the types of DC found in steady state lymphoid tissue (17). The culture model finally developed for generation of the type of DCs found in steady state became bone marrow stimulated with Flt3 ligand, rather that with $\operatorname{GM}-\operatorname{CSF}(30,31)$. Thus, the developmental pathway leading to DC functions became a major criterion for segregating and naming DC subtypes.

It was then possible to segregate DCs derived from monocytes from the cDCs found in steady state spleen. However, it is evident from the account above that our previous nomenclature of the subsets of spleen $\mathrm{cDCs}$ based on $\mathrm{CD} 8 \alpha$ expression was inadequate. Certain pDC subsets also expressed CD $8 \alpha$. Early DCs of "CD8 ${ }^{+}$cDC" lineage in spleen did not express $\mathrm{CD} 8 \alpha$. The migratory version of the same lineage, the $\mathrm{CD}_{103}{ }^{+} \mathrm{DCs}$, did not express it. And finally, CD8 was not expressed by human DCs. A major advance was the demonstration in several laboratories of an equivalent of the mouse " $\mathrm{CD} 8{ }^{+} \mathrm{cDC}$ " lineage within human DCs, and the finding that the chemokine receptor XCR1 and the C-type lectin-like molecule Clec9A, rather than CD8, served as common DC surface markers crossing this species barrier [commentary in Ref. (32)]. The proposed designation of this DC subtype as DC1 overcomes the previous nomenclature problems (33).

In contrast to these advances in understanding the DC1 subset, the $\mathrm{CD}^{-} \mathrm{CD}^{-} 1 \mathrm{~b}^{\text {high }}$ SIRP $\alpha^{\text {high }} \mathrm{cDCs}$ (designated as DC2) have been less studied and still present nomenclature issues. We had already separated spleen $\mathrm{CD}^{-}{ }^{-}$DCs into two subsets based on CD4 expression (5), but the significance of this remains obscure. A more meaningful separation can now be made based on surface expression of Clec12A (DCAL2, MICL) versus DCIR2 or ESAM $(6,34,35)$. An example of such segregation is shown in Figure 1. Importantly, these DC subsets differ in both developmental requirements and immunological characteristics; formation of $\mathrm{DCIR}^{+}{ }^{+} \mathrm{ESAM}^{\text {high }} \mathrm{Clec} 2 \mathrm{~A}^{-}$DCs requires Notch2 signaling and this subset selectively responds to flagellin and induces Th2 responses. Will these differences demand a further division into DC2 and DC3 subtypes? Or will one of these, particularly the

\section{References}

1. Steinman RM. Decisions about dendritic cells: past, present and future. Annu Rev Immunol (2011) 30:1-22. doi:10.1146/annurev-immunol-100311-102839

2. Shortman K, Wu L, Ardavin C, Vremec D, Stozik F, Winkel K, et al. Thymic dendritic cells: surface phenotype, developmental origin and function. In: Banchereau J, Schmitt D, editors. Dendritic Cells in Fundamental and Clinical Immunology. New York, NY: Plenum Publishing Corporation (1995). p. 21-9.

3. Vremec D, Zorbas M, Scollay R, Saunders DJ, Ardavin CF, Wu L, et al. The surface phenotype of dendritic cells purified from mouse thymus and spleen: investigation of the CD8 expression by a subpopulation of dendritic cells. J Exp Med (1992) 176:47-58. doi:10.1084/jem.176.1.47

4. Vremec D, Shortman K. Dendritic cell subtypes in mouse lymphoid organs: cross-correlation of surface markers, changes with incubation, and differences among thymus, spleen, and lymph nodes. J Immunol (1997) 159:565-73.

5. Vremec D, Pooley J, Hochrein H, Wu L, Shortman K. CD4 and CD8 expression by dendritic cell subtypes in mouse thymus and spleen. J Immunol (2000) 164:2978-86. doi:10.4049/jimmunol.164.6.2978

6. Lewis KL, Caton ML, Bogunovic M, Greter M, Grajkowska LT, Ng D, et al. Notch2 receptor signalling controls functional differentiation of dendritic cells in the spleen and intestine. Immunity (2011) 35:780-91. doi:10.1016/j.immuni. 2011.08.013
Clec12 $\mathrm{A}^{+}$subset, prove to be part of the monocyte-derived group? These questions require further work.

It is notable that ontogeny has led to a better understanding and provided one logical basis for DC classification (33). Will ontogeny be the best guide for DC nomenclature in future? We can foresee one area where it may cause confusion. A proportion of mouse pDCs and the CD8 $\alpha$-expressing subset of $\mathrm{cDCs}$ in the mouse thymus have a potential route of development from lymphoid rather than myeloid precursors $(36,37)$. These DC types have D-J rearrangements in their Ig heavy chain genes, a characteristic of lymphoid-origin cells (38). The extent to which a lymphoid route contributes to their development in steady state is still unclear, but the potential is there. Yet, the thymic CD8 ${ }^{+}$ DCs are similar to the splenic $\mathrm{CD}^{+}$DCs of myeloid origin, and $\mathrm{pDC}$ developing from myeloid or lymphoid precursors have similar surface phenotype and immunological functions. Should they have separate names according to their developmental origin, or should this "convergent" development lead to cells with the same name? There may yet be fine differences in function that eventually will be important to specify, but at present they are called by the same name. One resolution of this paradox comes from the likelihood that, despite the differences in bone marrow precursor surface markers, a common molecular program for $\mathrm{pDC}$ or for $\mathrm{CD}^{+}{ }^{+} \mathrm{cDC}$ formation has been initiated, with transcription factors that override any previous precursor orientation. Considering ontological origin in terms of these final molecular programs, rather than by the surface markers on the precursor cells, should overcome the paradox resulting from apparent convergent differentiation.

\section{Acknowledgments}

Our research was supported by the National Health and Medical Research Council, Australia and was made possible through the Victorian State Government Operational Infrastructure Support and Australian Government NHMRC IRIISS.

7. Shortman K, Heath WR. The CD8 ${ }^{+}$dendritic cell subset. Immunol Rev (2010) 234:18-31. doi:10.1111/j.0105-2896.2009.00870.x

8. Hochrein H, Shortman K, Vremec D, Scott B, Hertzog P, O’Keeffe M. Differential production of IL-12, IFN-alpha, and IFN-gamma by mouse dendritic cell subsets. J Immunol (2001) 166:5448-55. doi:10.4049/jimmunol.166.9.5448

9. Pooley JL, Heath WR, Shortman K. Cutting edge: intravenous soluble antigen is presented to CD4 T cells by CD8- dendritic cells, but cross-presented to CD8 T cells by $\mathrm{CD}^{+}$dendritic cells. J Immunol (2001) 166:5327-30. doi:10.4049/ jimmunol.166.9.5327

10. Schnorrer P, Behrens GM, Wilson NS, Pooley JL, Smith CM, El-Sukkari D, et al. The dominant role of $\mathrm{CD}^{+}$dendritic cells in cross-presentation is not dictated by antigen capture. Proc Natl Acad Sci U S A (2006) 103:10729-34. doi:10.1073/pnas.0601956103

11. Naik S, Vremec D, Wu L, O’Keeffe M, Shortman K. CD $8 \alpha^{+}$mouse spleen dendritic cells do not originate from the $\mathrm{CD} 8 \alpha^{-}$dendritic cell subset. Blood (2003) 102:601-4. doi:10.1182/blood-2002-10-3186

12. Bedoui S, Prato S, Mintern J, Gebhardt T, Zhan Y, Lew A, et al. Characterisation of an intermediate splenic precursor of $\mathrm{CD}^{+}$dendritic cells capable of inducing antiviral T cell responses. J Immunol (2009) 182:4200-7. doi:10.4049/jimmunol. 0802286

13. Sathe P, Pooley J, Vremec D, Mintern J, Jin JO, Wu L, et al. The acquisition of antigen cross-presentation function by newly formed dendritic cells. J Immunol (2011) 186:5184-92. doi:10.4049/jimmunol.1002683 
14. Asselin-Paturel C, Boonstra A, Dalod M, Durand I, Yessaad N, DezutterDambuyant C, et al. Mouse type I IFN-producing cells are immature APCs with plasmacytoid morphology. Nat Immunol (2001) 2:1144-50. doi:10.1038/ni736

15. O’Keeffe M, Hochrein H, Vremec D, Caminschi I, Miller JL, Anders EM, et al. Mouse plasmacytoid cells: long-lived cells, heterogeneous in surface phenotype and function, that differentiate into $\mathrm{CD} 8 \alpha^{+}$dendritic cells only after microbial stimulus. J Exp Med (2002) 196:1307-19. doi:10.1084/jem.20021031

16. Naik SH, Metcalf D, van Nieuwenhuijze A, Wicks I, Wu L, O'Keeffe M, et al. Intrasplenic steady-state dendritic cell precursors that are distinct from monocytes. Nat Immunol (2006) 7:663-71. doi:10.1038/ni1340

17. Shortman K, Naik SH. Steady-state and inflammatory dendritic-cell development. Nat Rev Immunol (2007) 7:19-30. doi:10.1038/nri1996

18. Naik SH, Sathe P, Park H-Y, Metcalf D, Proietto AI, Dakic A, et al. Development of plasmacytoid and conventional dendritic cell subtypes from single in vitro and in vivo-derived precursors. Nat Immunol (2007) 8:1217-26. doi:10.1038/ ni1522

19. Salomon B, Cohen JL, Masurier C, Klatzmann D. Three populations of mouse lymph node dendritic cells with different origins and dynamics. J Immunol (1998) 160:708-17.

20. Anjuere F, Martin P, Ferraro I, Frage GM, del Hoyo GM, Wright N, et al. Definition of dendritic cell populations present in the spleen, Peyer's patches, lymph nodes, and skin of the mouse. Blood (1999) 93:590-8.

21. Henri S, Vremec D, Kamath A, Waithman J, Williams S, Benoist C, et al. The dendritic cell populations of mouse lymph nodes. J Immunol (2001) 167:741-8. doi:10.4049/jimmunol.167.2.741

22. Wilson NS, El-Sukkari D, Belz GT, Smith CM, Steptoe RJ, Heath WR, et al. Most lymphoid organ dendritic cell types are phenotypically and functionally immature. Blood (2003) 102:2187-94. doi:10.1182/blood-2003-02-0513

23. Vremec D, O'Keeffe M, Wilson A, Ferrero I, Koch U, Radtke F, et al. Factors determining the spontaneous activation of splenic dendritic cells in culture. Innate Immun (2011) 17:338-52. doi:10.1177/1753425910371396

24. Poulin LF, Henri S, de Bovis B, Devilard E, Kissenpfennig A, Malissen B. The dermis contains langerin+ dendritic cells that develop and function independently of epidermal Langerhans cells. J Exp Med (2007) 24:3119-31. doi:10. 1084/jem.20071724

25. Ginhoux F, Collin MP, Bogunovic M, Abel M, Leboeuf M, Helft J, et al. Bloodderived dermal langerin + dendritic cells survey the skin in the steady state. J Exp Med (2007) 204:3133-46. doi:10.1084/jem.20071733

26. Bursch LS, Wang L, Igyarto B, Kissenpfennig A, Malissen B, Kaplan DH, et al. Identification of a novel population of langerin ${ }^{+}$dendritic cells. $J$ Exp Med (2007) 204:3147-56. doi:10.1084/jem.20071966

27. Sallusto F, Lanzavecchia A. Efficient presentation of soluble antigen by cultured human dendritic cells is maintained by granulocyte/macrophage colonystimulating factor plus interleukin 4 and downregulated by tumor necrosis factor alpha. J Exp Med (1994) 179:1109-18. doi:10.1084/jem.179.4.1109
28. Hume DA. Macrophages as APC and the dendritic cell myth. J Immunol (2008) 181:5829-35. doi:10.4049/jimmunol.181.9.5829

29. Metcalf D, Shortman K, Vremec D, Mifsud S, Di Rago L. Effects of excess GMCSF levels on hematopoiesis and leukemia development in GM-CSF/max 41 double transgenic mice. Leukemia (1996) 10:713-9.

30. Brasel K, De Smedt T, Smith JL, Maliszewski CR. Generation of murine dendritic cells from flt-3-ligand-supplemented bone marrow cultures. Blood (2000) 96:3029-39.

31. Naik SH, Proietto AI, Wilson NS, Dakic A, Schnorrer P, Fuchsberger M, et al Cutting edge: generation of splenic $\mathrm{CD}^{+}$and $\mathrm{CD}^{-}$dendritic cell equivalents in Fms-like tyrosine kinase 3 ligand bone marrow cultures. J Immunol (2005) 174:6592-7. doi:10.4049/jimmunol.174.11.6592

32. Villadangos JA, Shortman K. Found in translation: the human equivalent of mouse CD8 ${ }^{+}$dendritic cells. J Exp Med (2010) 207:1131-4. doi:10.1084/jem. 20100985

33. Guilliams M, Ginhoux F, Jakubzinck C, Naik S, Onai N, Schraml BU, et al. Dendritic cells, monocytes and macrophages - a proposal for a unifying nomenclature based on ontogeny. Nat Rev Immunol (2014) 14:571-8. doi:10.1038/ nri3712

34. Lahoud MH, Proietto A, Ahmet F, Kitsoulis S, Eidsmo L, Wu L, et al. The Ctype lectin Clec12A present on mouse and human dendritic cells can serve as a target for antigen delivery and enhancement of antibody responses. J Immunol (2009) 182:7587-94. doi:10.4049/jimmunol.0900464

35. Kasahara S, Clark EA. Dendritic cell associated lectin 2 (DCAL2) defines a distinct CD8 $\alpha$ dendritic cell subset. J Leukoc Biol (2012) 91:418-37. doi:10. 1189/jlb.0711384

36. Shortman K, Sathe P, Vremec D, Naik S, O'Keeffe M. Plasmacytoid dendritic cell development. Adv Immunol (2013) 120:105-26. doi:10.1016/ B978-0-12-417028-5.00004-1

37. Ardavin C, Wu L, Li CL, Shortman K. Thymic dendritic cells and T cells develop simultaneously within the thymus from a common precursor population. Nature (1993) 362:761-3. doi:10.1038/362761a0

38. Corcoran L, Ferrero I, Vremec D, Lucas K, Waithman J, O’Keeffe M, et al The lymphoid past of mouse plasmacytoid cells and thymic dendritic cells. $J$ Immunol (2003) 170:4926-32. doi:10.4049/jimmunol.170.10.4926

Conflict of Interest Statement: The authors declare that the research was conducted in the absence of any commercial or financial relationships that could be construed as a potential conflict of interest.

Copyright (c) 2015 Vremec and Shortman. This is an open-access article distributed under the terms of the Creative Commons Attribution License (CC BY). The use, distribution or reproduction in other forums is permitted, provided the original author(s) or licensor are credited and that the original publication in this journal is cited, in accordance with accepted academic practice. No use, distribution or reproduction is permitted which does not comply with these terms. 